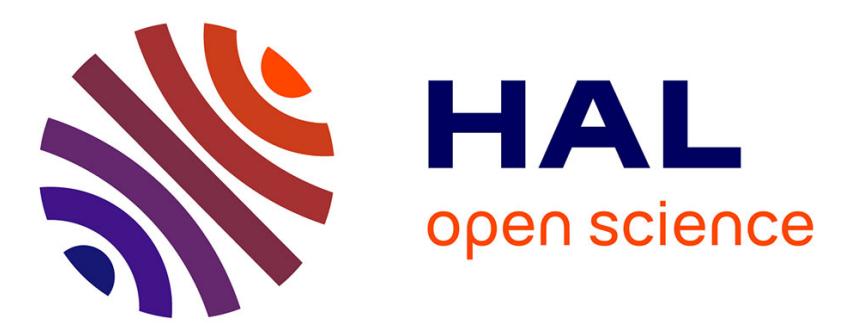

\title{
Structure of Collybia fusipes populations in two infected oak stands
}

Benoit Marçais, F. Martin, C. Delatour

\section{To cite this version:}

Benoit Marçais, F. Martin, C. Delatour. Structure of Collybia fusipes populations in two infected oak stands. Mycological Research, 1998, 102 (3), pp.361-367. 10.1017/S0953756297005017. hal02058967

\section{HAL Id: hal-02058967 \\ https://hal.science/hal-02058967}

Submitted on 6 Mar 2019

HAL is a multi-disciplinary open access archive for the deposit and dissemination of scientific research documents, whether they are published or not. The documents may come from teaching and research institutions in France or abroad, or from public or private research centers.
L'archive ouverte pluridisciplinaire HAL, est destinée au dépôt et à la diffusion de documents scientifiques de niveau recherche, publiés ou non, émanant des établissements d'enseignement et de recherche français ou étrangers, des laboratoires publics ou privés. 


\title{
Mycological Research 1998
}

102 (3): 361-372

Doi : $\underline{10.1017 / S 0953756297005017}$

\section{Structure of Collybia fusipes population in two infected oak stands}

\author{
B. Marçais, F. Martin and C. Delatour \\ Unité des Ecosystèmes Forestiers, Laboratoires de Pathologie Forestière et de \\ Microbiologie. Institut National de la Recherche Agronomique, 54280 Champenoux, France
}

Collybia fusipes is the cause of a root rot of oak trees (Quercus petraea, Q. robur, $Q$. rubra). We studied the structure of $C$. fusipes populations in two infected oak stands by using somatic incompatibility and DNA amplification. Isolates were obtained from different oak root systems or from within the same root system and somatic incompatibility groups (SIG) were identified. Many small SIGs that seldom encompassed more than one root system were present in both stands. More than one SIG was usually present on an individual root system: there were $3.1 \pm 1.3$ SIGs on the pedunculate oaks and $2.2 \pm 0.6$ on the red oaks. The largest SIG contained more than $70 \%$ of the isolates obtained from the root system of fourteen of the twenty studied trees. Isolates that belonged to the same SIG usually had the same ribosomal intergenic spacer. It is concluded that $C$. fusipes spreads poorly from tree to tree by vegetative means.

\section{INTRODUCTION}

Collybia fusipes (Bull. Ex Fr.) Quél. is a very common fungus in France. It occurs mainly at the base of the trunk on living oaks (Quercus petraea (Matt.) Liebl., Q. robur L., Q. rubra L.) and on stumps (Département de Santé des Forêts, 1994). Although it has been well known by mycologists for a long time, $C$. fusipes was only recently reported to be a root pathogen of mature oaks in forest conditions (Delatour \& Guillaumin, 1984; Guillaumin et al., 1985). Thus, very little information is available on the epidemiology and virulence of this root rot fungus. In particular, the way in which $C$. fusipes spreads from tree to tree, a very important epidemiological feature, is unknown.

C. fusipes produces cordlike structures called pseudorhiza (Buller, 1958). These structures remain attached to host roots and are found growing free in the soil only when they grow from infected tissues to the soil surface and support fruit bodies. They are quite common on the surface of infected roots and could be involved in the spread of $C$. fusipes within and between the root systems of host trees (Marçais \& Delatour, 1996). C. fusipes is known to sporulate abundantly from mid-June to the end of September (Département de Santé des Forêts, 1994) and, therefore, basidiospores also could be important in the spread of this fungus. The population structure of $C$. fusipes within a stand should indicate which method of dispersal, vegetative growth or basidiospores, is prevalent. If spread from tree to tree occurs through root contacts, genets of $C$. fusipes should be infrequent and occupy large 
areas, encompassing many trees. By contrast, if basidiospores are an important means of dispersal, genets should be frequent in number and occupy small areas, including only one or a small number of trees.

Population structure has been successfully used to indicate the way other root infecting fungi spread within infected stands. It was concluded that vegetative growth was prevalent for Phellinus weirii and Armillaria luteobubalina because they formed large foci in which only one or a few large genets were present (Childs, 1963; Kile, 1983; Bae et al., 1994). Other Armillaria species use both basidiospores and vegetative growth to spread and their population structure in infected stands can either be formed by a high number of genets, few of them attaining a very large size, or a few large genets (Kile, 1986; Guillaumin \& Berthelay, 1990; Smith, Bruhn \& Anderson, 1992; Worral, 1994). Basidiospores were deemed the main means of dispersal for Phaeolus schweinizii and Inonotus tomentosus because their genets were small and encompassed either one or a small number of trees (Barrett \& Uscuplic, 1971; Lewis \& Hansen, 1991). In all those studies, somatic incompatibility, i.e., the interaction that develops between two different heterokaryotic isolates when paired together in culture, was found to be a very useful tool to characterize the population structure of root infecting fungi.

We studied the structure of $C$. fusipes populations in two infected stands of oaks, using somatic incompatibility and amplification of the ribosomal intergenic spacer. We looked at the population structure at the stand level and also at the individual root system level because we wanted to gain some insight on the way C. fusipes infects its host.

\section{MATERIALS AND METHODS}

\section{Sample collection and isolation procedures}

Two stands were selected for the study. The first was a coppice with standard stand stocked mainly with pedunculate oaks ( $Q$. robur) and hornbeams and located at Mersuay (parcelle 5, Forêt communale de Mersuay, Haute Saône, France). The study plot was 2 ha. The second was a 1.1 ha red oak stand (Q. rubra), originating from a natural regeneration in 1924-28 and located at Les Barres (Glandée d'Amérique, Arboretum des Barres, Loiret, France). A 0.8 ha portion of this stand was studied.

At Les Barres, the occurrence of $C$. fusipes fruit bodies on 74 trees had been observed for three years (D. Piou, personnal communication). Infected root tissues were sampled on all the trees on which $C$. fusipes fruit bodies had occurred in at least one of the three years. At Mersuay, infected root tissues were sampled on all the trees on which $C$. fusipes fruit bodies were present by the end of June 1993. The structure of $C$. fusipes population on individual root systems was also studied on nine trees from Les Barres and eight trees from Mersuay. Root systems were partially excavated (distance of $80 \mathrm{~cm}$ from collar and depth of $30 \mathrm{~cm}$ ), occurrences of $C$. fusipes induced lesions were recorded, and portions of diseased root tissues were sampled from 8-12 scattered locations. Two more pedunculate oaks located in Aillevans and Longevelle, close to Mersuay (Haute Saône) were sampled with the same technique. One red oak in Les Barres was completely uprooted and 60 samples were collected. Isolations from infected root samples were made on MAT 
selective medium (15 g of Agar, $10 \mathrm{~g}$ of Malt, $250 \mathrm{mg}$ of Thiabendazol, $100 \mathrm{mg}$ of penicillin, $100 \mathrm{mg}$ of streptomycin, 1 I of distilled water).

\section{Somatic incompatibility tests}

C. fusipes isolates were paired by placing $4 \mathrm{~mm}^{2}$ agar blocks containing actively growing mycelium $5 \mathrm{~mm}$ apart on cristomalt medium (15 g of Agar, $20 \mathrm{~g}$ of cristomalt, 1 I of distilled water). One replicate was done for each pairing. The morphology of the interaction was observed after incubation at room temperature for 15,30 and 45 days. Pairings were rated as: 0 , compatible or no reaction; 1 , incompatible, light pigmentation appearing at 30 days after incubation; 2, incompatible, heavy pigmentation present 15 days after incubation.

Isolates originating from the same tree were treated as follows. All isolates were paired against one isolate from the tree. This enabled us to define a first somatic incompatibility group (SIG). The remaining isolates were paired against an isolate that did not belong to the first SIG. This was repeated until the SIG of only 3-4 isolates remained unknown. Those 3-4 isolates were then paired together in all combination. For each SIG, the results were checked in a second experiment by pairing the isolates of each SIG in all combinations.

In each plot, isolates from all trees were paired in all combinations. For the trees on which several isolates had been collected, just one isolate of each SIG present on the root system was included in the study. All pairings that were rated 0 or 1 were repeated in a second experiment.

\section{DNA extraction and PCR amplification}

The ribosomal intergenic spacer (IGS) was studied on a total of 68 isolates belonging to 26 of the SIGs (34 from Les Barres and 34 from Mersuay; 5-6 isolates per SIG; see Table 2). All the procedure, DNA extraction, amplification and electrophoresis was replicated 2 times.

Total DNA was extracted by the hexadecyltrimethylammonium (CTAB) / proteinase $\mathrm{K}$ procedure, essentially as described by Henrion, Chevalier \& Martin (1994). Amplification of the $25 \mathrm{~S} / 5 \mathrm{~S}$ spacer $\left(\mathrm{IGS}_{1}\right)$ was carried out using the primers LB25S1 (5'-GCTACGATCCGCTGAGGTTAA-3') and 5SA (5'CAGAGTCCTATGGCCGTGGAT-3') with priming sites at the 3' end of the 25S gene and the 5 ' end of the $5 S$ gene, respectively (Henrion, Le Tacon \& Martin, 1992). The sequence containing the $5 S$ rDNA plus $5 S / 17 S$ spacer $\left(\mathrm{IGS}_{2}\right)$ was amplified with primers rev5SA (5'-ATCCACGGCCATAGGACTCTG-3'), the reverse complement of primer 5SA, and revNS1 (5'-GAGACAAGCATATGACTAC-3'), the reverse complement of primer NS1 (White et al., 1990), with priming sites at the 5 ' end of the $5 S$ gene and the $5^{\prime}$ end of the $17 S$ gene respectively. Primers were supplied by Bioprobe Systems (Montreuil-sous-bois, France). PCR amplifications were carried out in reactions lots of $25 \mu$ l containing $0.3-0.6 \mathrm{ng}$ DNA, $100 \mathrm{mM}$ TrisHCl $(\mathrm{pH} 8.8$ at $25^{\circ} \mathrm{C}$ ), $1.5 \mathrm{mM} \mathrm{MgCl}_{2}, 50 \mathrm{mM} \mathrm{KCl}, 0.1 \%$ Triton X-100, $200 \mu \mathrm{M}$ dNTP mix, 10 pmol primers and $0.6 \mathrm{U}$ of Taq Polymerase (Bioprobe Systems). For IGS 2 amplification, the dNTP concentration was increased to $400 \mu \mathrm{M}$. Reactions were performed in a Eurojantec ThermoJet cycler under the following regime: initial denaturation at $93^{\circ} \mathrm{C}$ for $3 \mathrm{~min}$, followed by 35 cycles of denaturation at $93^{\circ} \mathrm{C}$ for $1 \mathrm{~min}$, annealing at $50^{\circ} \mathrm{C}$ for $30 \mathrm{~s}$, and extension at $72^{\circ} \mathrm{C}$ for $1 \mathrm{~min}$ with a final extension at $72^{\circ} \mathrm{C}$ for $10 \mathrm{~min}$. 
For amplification of IGS 2 , extension periods were increased to 5 min during cycles and $15 \mathrm{~min}$ for final extension. Negative controls (no DNA template) were included for each set of experiments to test for the presence of DNA contamination. The amplified products were subjected to electrophoresis on $0.8 \%$ agarose gels, stained with ethidium bromide and visualized under UV light.

$\mathrm{IGS}_{2}$ was cut with a restriction enzyme. About $1-2 \mu \mathrm{g}$ of amplified DNA was digested overnight with $5 \mathrm{U}$ of Hae III (Sigma chimie) according to the manufacturer's instructions. Restriction fragments were subjected to electrophoresis on NuSieve gels (1.5\% agarose 'Wide Range', Sigma chimie, $0.5 \%$ agarose, Bioprobe systems).

Table 1. Somatic incompatibility groups (SIG) of Collybia fusipes present in the root system of twenty oak trees.

\begin{tabular}{ccccc}
\hline Plot & species & $\begin{array}{c}\text { Number of } \\
\text { Tree }\end{array}$ & $\begin{array}{c}\text { Number of } \\
\text { is }\end{array}$ & $\begin{array}{c}\text { Number of isolates } \\
\text { in the largest SIG a }\end{array}$ \\
\hline Mersuay & Q. robur & & & \\
M 14 & & 11 & 1 & $11(100 \%)$ \\
M 45 & 8 & 2 & $8(100 \%)$ \\
M 60 & 11 & 5 & $10(91 \%)$ \\
M 65 & 10 & 2 & $3(30 \%)$ \\
M 66 & 12 & 5 & $11(92 \%)$ \\
M 67 & 10 & 2 & $6(60 \%)$ \\
M 69 & 9 & 6 & $5(56 \%)$ \\
M 70 & & 6 & $2(25 \%)$ \\
Aillevans & & 17 & 1 & $10(100 \%)$ \\
Longevelle & Q. robur & 10 & & \\
Barres & Q. robur & & 1 & $60(100 \%)$ \\
B 0 & Q. rubra & 60 & 1 & $10(100 \%)$ \\
B 39 & & 10 & 2 & $8(80 \%)$ \\
B 41 & & 10 & 3 & $10(83 \%)$ \\
B 55 & & 12 & 2 & $10(91 \%)$ \\
B 91 & & 11 & 2 & $6(60 \%)$ \\
B 92 & & 2 & 2 & $10(100 \%)$ \\
B 99 & & 10 & 1 & $5(71 \%)$ \\
B 100 & & 3 & $9(82 \%)$ \\
B 102 & & 11 & 3 & $7(70 \%)$ \\
B 103 & & 10 & 4 &
\end{tabular}

\footnotetext{
a Number in parentheses indicates the proportion of the total number of isolates sampled on the tree represented by the SIG

b Tree completly uprooted
}

\section{RESULTS}

\section{Somatic incompatibility tests}

Isolates of $C$. fusipes were obtained from 34 different pedunculate oaks at Mersuay and from 31 different red oaks at Les Barres (Figs $1 \& 2$ ). Pairings between isolates from the same tree gave a compatible interaction (rating of 0 ) in $65 \%$ of the cases. When the compatible interactions were repeated in a second experiment, all were rated 0 again. Among the incompatible interactions, $14 \%$ for Mersuay and $18 \%$ for Les Barres were rated as 1 (lightly pigmented interaction). The mean number of 
SIGs per root system was of $3.1 \pm 1.3$ for the pedunculate oaks (Aillevans, Longevelle and Mersuay) and of $2.2 \pm 0.6$ for the red oaks (Les Barres). However, for the majority of the root systems, most of the isolates belonged to one large SIG (Table 1). When several SIGs of comparable size were present on a root system, isolates which belonged to the same SIG were spatially close (Fig. 3).
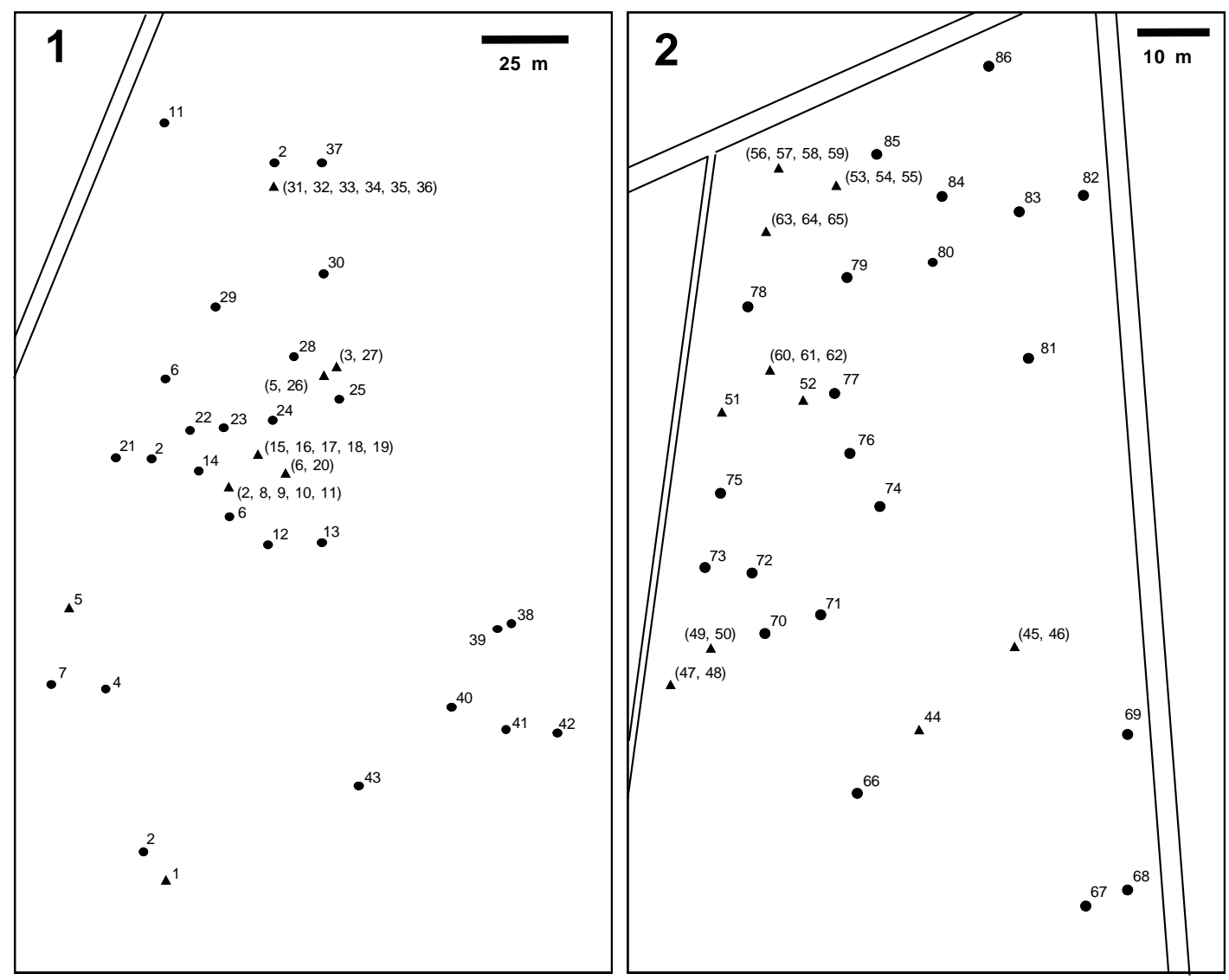

Figures 1 - 2. Distribution of Collybia fusipes somatic incompatibility groups (SIG). Fig.1. Mersuay. Fig. 2. Les Barres. •, trees for which one $C$. fusipes isolate is available; $\mathbf{\wedge}$, trees for which several $C$. fusipes isolates are available. Numbers indicate the SIGs present on the tree.

Unlike isolates that came from the same tree, those collected on different trees gave incompatible interactions in $98.6 \%$ of the pairings for Mersuay and in all of them for Les Barres. Even trees separated by just few meters were usually infected with isolates belonging to different SIGs (Figs $1 \& 2$ ). In the Mersuay plot, the trees infected with isolates from the same SIG were scattered within the stand (SIGs 2, 5, 6 and 11, Fig. 1). About $12 \%$ of the incompatible pairings between isolates from two different trees were rated as 1 in both plots. When repeated in a second experiment, these pairings were all rated 1 again. These weaker interactions showed transitiveness (when pairing between $A$ and $B$ and that between $B$ and $C$ were rated as 1 , pairing between $A$ and $C$ was always rated as 1). Therefore, isolates showing a weaker incompatibility together could be grouped. Eleven of those groups were 
present in Mersuay and nine in Les Barres. Isolates from those groups were scattered within the stands.

All together, including the single isolates from each tree and the multiple isolates from individual root systems, 43 SIGs were identified in Mersuay and 43 in Les Barres.

Table 2. IGS type of the isolates studied by PCR analysis. Isolates are grouped according to the SIG.

\begin{tabular}{|c|c|c|c|c|c|c|c|}
\hline SIG & Isolate & $\begin{array}{l}\mathrm{IGS}_{1} \\
\text { type }\end{array}$ & $\begin{array}{c}\mathrm{IGS}_{2} \\
\text { type }\end{array}$ & SIG & Isolate & $\begin{array}{l}\mathrm{IGS}_{1} \\
\text { type }\end{array}$ & $\begin{array}{c}\mathrm{IGS}_{2} \\
\text { type }\end{array}$ \\
\hline 1 & $\mathrm{M}_{45.1}{ }^{\mathrm{a}}$ & 1 & 1 & 44 & $\mathrm{~B}_{39.1}$ & 1 & 12 \\
\hline 1 & $M_{45.2}$ & 1 & 1 & 44 & $B_{39.3}$ & 1 & 12 \\
\hline 1 & $M_{45.3}$ & 1 & 1 & 44 & $B_{39.5}$ & 1 & 12 \\
\hline 1 & $M_{45.4}$ & 1 & 1 & 44 & $\mathrm{~B}_{39.7}$ & 1 & 12 \\
\hline 1 & $M_{45.8}$ & 1 & 1 & 44 & $B_{39.9}$ & 1 & 12 \\
\hline 2 & $M_{16}$ & 1 & 2 & 47 & $\mathrm{~B}_{91.2}$ & 1 & 13 \\
\hline 2 & $\mathrm{M}_{44}$ & 1 & 3 & 47 & $\mathrm{~B}_{91.4}$ & 1 & 13 \\
\hline 2 & $M_{65.1}$ & 1 & 4 & 47 & $\mathrm{~B}_{91.6}$ & 1 & 13 \\
\hline 2 & $M_{65.2}$ & 1 & 4 & 47 & $\mathrm{~B}_{91.8}$ & 1 & 13 \\
\hline 2 & $M_{65.10}$ & 1 & 4 & 47 & $\mathrm{~B}_{91.11}$ & 1 & 13 \\
\hline 3 & $M_{60.1}$ & 1 & 5 & 51 & $B_{99.1}$ & 1 & 14 \\
\hline 3 & $M_{60.2}$ & 1 & 5 & 51 & B99.4 & 1 & 14 \\
\hline 3 & $M_{60.5}$ & 1 & 5 & 51 & B99.6 & 1 & 14 \\
\hline 3 & $M_{60.7}$ & 1 & 5 & 51 & $\mathrm{~B}_{99.8}$ & 1 & 14 \\
\hline 3 & $M_{60.9}$ & 1 & 5 & 51 & $\mathrm{~B}_{99.10}$ & 1 & 14 \\
\hline 5 & $M_{141}$ & 1 & 6 & 53 & $\mathrm{~B}_{55,3}$ & 1 & 15 \\
\hline 5 & $M_{69.5}$ & 2 & 4 & 53 & $B_{55.5}$ & 1 & 15 \\
\hline 5 & $M_{69.6}$ & 2 & 4 & 53 & $\mathrm{~B}_{55.7}$ & 1 & 15 \\
\hline 5 & $M_{69.7}$ & 2 & 4 & 53 & $B_{55.9}$ & 1 & 15 \\
\hline 5 & $M_{69.8}$ & 2 & 4 & 53 & $\mathrm{~B}_{55.11}$ & 1 & 15 \\
\hline \multirow[t]{2}{*}{5} & $M_{69.9}$ & 2 & 4 & & & & \\
\hline & & & & 56 & $\mathrm{~B}_{1034}$ & 1 & 6 \\
\hline 6 & $M_{62}$ & 2 & ND & 56 & $\mathrm{~B}_{103.5}$ & 1 & 6 \\
\hline 6 & $M_{66.3}$ & 3 & 3 & 56 & $\mathrm{~B}_{103.7}$ & 1 & 6 \\
\hline 6 & $M_{66.4}$ & 3 & 3 & 56 & $\mathrm{~B}_{103.9}$ & 1 & 6 \\
\hline 6 & $M_{66.6}$ & 3 & 3 & 56 & $B_{103.10}$ & 1 & 6 \\
\hline 6 & $M_{66.8}$ & 3 & 3 & & & & \\
\hline \multirow[t]{2}{*}{6} & $M_{66.10}$ & 3 & 3 & 60 & $B_{100.3}$ & 1 & 15 \\
\hline & & & & 63 & $\mathrm{~B}_{102.2}$ & 2 & 4 \\
\hline 7 & $M_{11}$ & 2 & 7 & 64 & $\mathrm{~B}_{102.10}$ & 2 & 4 \\
\hline 9 & $M_{65.9}$ & 2 & 4 & 66 & $\mathrm{~B}_{23}$ & 1 & 6 \\
\hline 15 & $M_{67.2}$ & 1 & 8 & 69 & $\mathrm{~B}_{18}$ & 2 & 4 \\
\hline 16 & $M_{67.4}$ & 1 & 9 & 70 & B93 & 1 & 16 \\
\hline 22 & $M_{18}$ & 2 & 10 & 72 & $\mathrm{~B}_{95}$ & 2 & 15 \\
\hline 27 & $M_{60.4}$ & 2 & 11 & 81 & $\mathrm{~B}_{8}$ & 2 & 4 \\
\hline 28 & $M_{25}$ & 2 & 3 & 86 & $\mathrm{~B}_{2}$ & 1 & 3 \\
\hline
\end{tabular}

\footnotetext{
$\mathrm{a}_{45.1}$ is isolate number 1 from the tree $M_{45}$.
} 


\section{Amplification of the intergenic spacer}

The amplification priming sites were selected from highly conserved regions found in the 17S, 5S and 25S regions adjacent to the IGS spacers (White et al., 1990; Henrion et al., 1992). Amplification of the $5 \mathrm{~S} / 17 \mathrm{~S}$ spacer $\left(\mathrm{IGS}_{2}\right)$ of $C$. fusipes produced one to three fragments ranging from 2100 to 2700 base pairs (Fig. 4), whereas amplification of the 25S/5S spacer $\left(I_{G S}\right)$ generated three or four fragments of $1070,800,737$ and 480 base pairs. Three different banding patterns were evidenced for IGS 1 and sixteen different IGS 2 types were detected (Table 2). Variability in the IGS 2 was mainly linked to different numbers and size of amplified DNA fragments (Fig. 4). However, additional variability was detected among the 64 isolates by cutting the $\mathrm{IGS}_{2}$ with $\mathrm{Hae}$ III (Fig. 5). Isolates which belonged to the same SIG generally had the same IGS ${ }_{1}$ and IGS 2 type. SIGs 2, 5 and 6 were the only groups in which all isolates did not have both the same IGS 1 and IGS 2 . These were also the only SIGs in which isolates from different trees were present (Table 2).

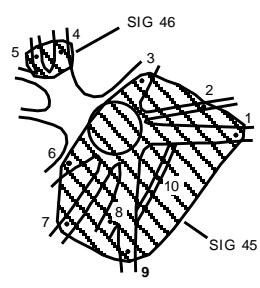

Les Barres, tree B41

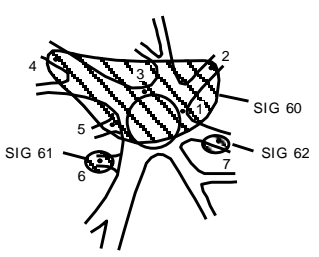

Les Barres, tree B100

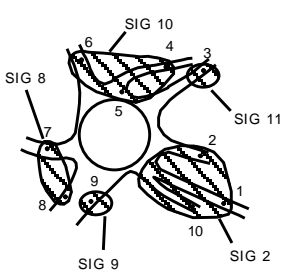

Mersuay, tree M65

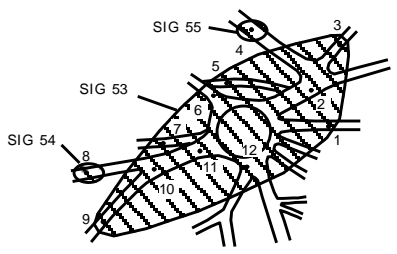

Les Barres, tree B55

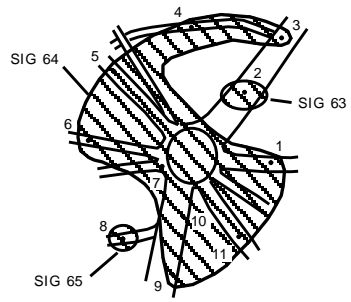

Les Barres, tree B102

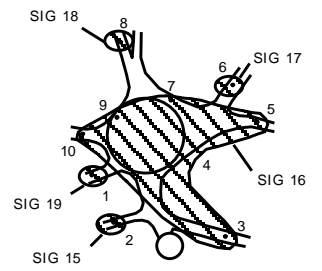

Mersuay, tree M67

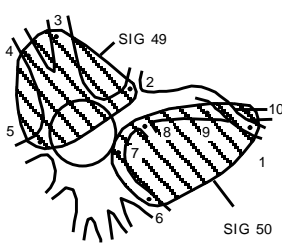

Les Barres, tree B92

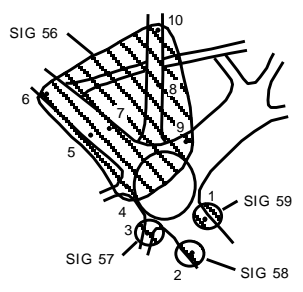

Les Barres, tree B103

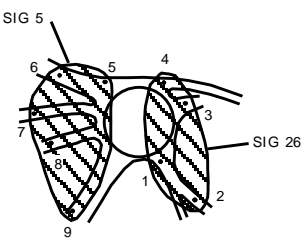

Mersuay, tree M69

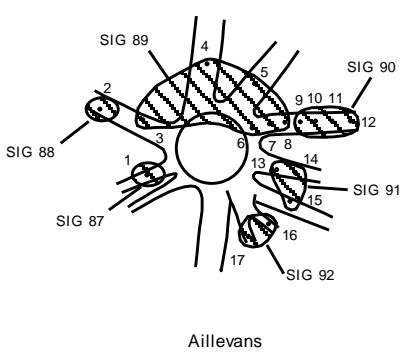

Aillevans

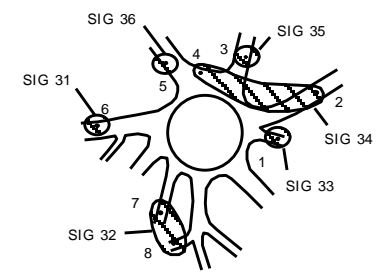

Mersuay, tree M70

Figure 3. Distribution of Collybia fusipes somatic incompatibility groups (SIG) on the root system of $Q$. robur and $Q$. rubra. Just the trees in which the largest SIG represent less than $90 \%$ of the total number of isolate are shown. 

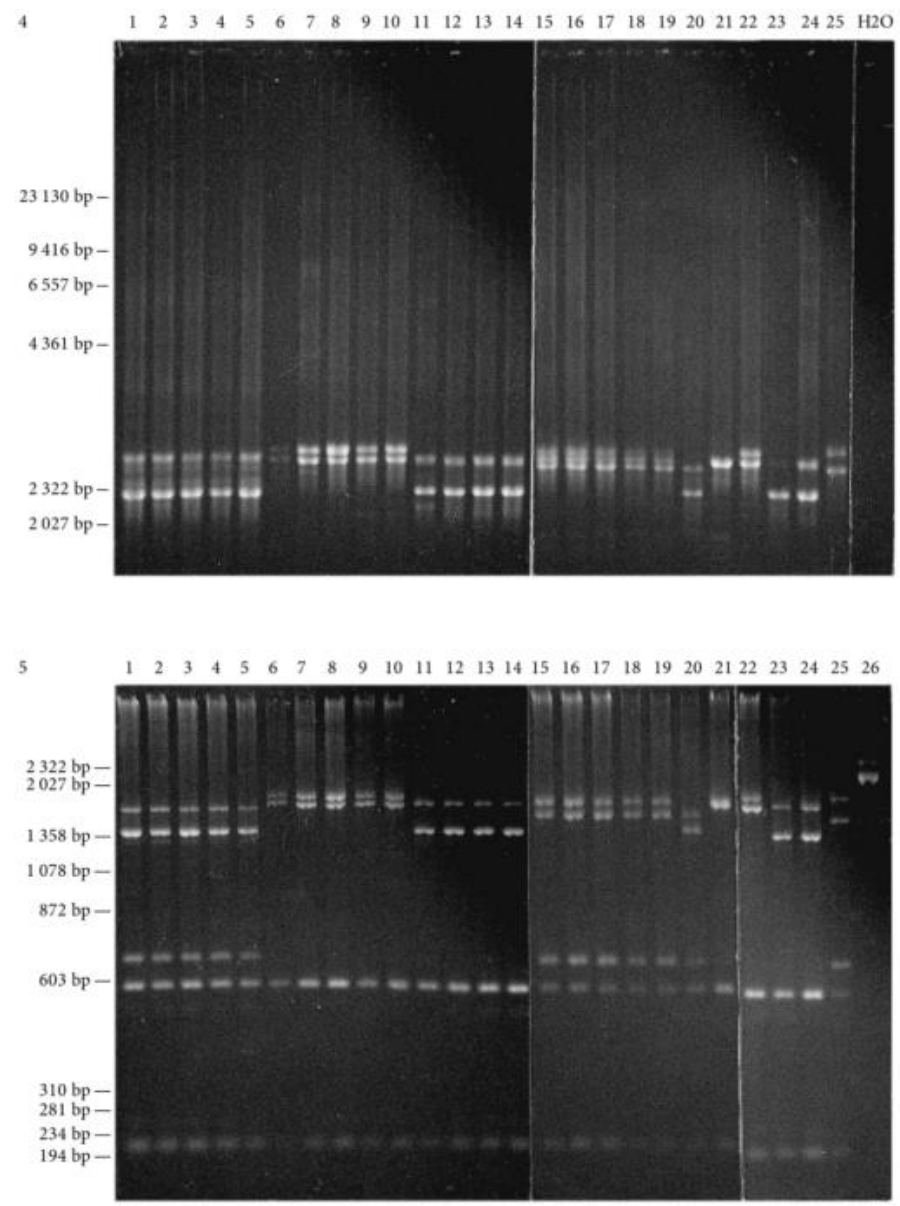

Figures 4 - 5. Ribosomal DNA intergenic spacer IGS 2 in Collybia fusipes isolates from Mersuay (Haute Saône, France). Fig. 4. DNA fragments amplified with the primer pair NS1' / 5SA'. Fig.5. DNA fragments amplified with the primer pair $\mathrm{NS}^{\prime} / 5 \mathrm{SA}^{\prime}$ and cut by Hae III. Lines $1: \mathrm{M}_{45.1} ; 2: \mathrm{M}_{45.2} ; 3: \mathrm{M}_{45.3} ; 4: \mathrm{M}_{45.4} ; 5: \mathrm{M}_{45.8} ; 6: \mathrm{M}_{60.1} ; 7: \mathrm{M}_{60.2} ; 8: \mathrm{M}_{60.5} ; 9: \mathrm{M}_{60.7}$; 10: $M_{60.9} ; 11: M_{66.3} ; 12: M_{66.4} ; 13: M_{66.6} ; 14: M_{66.8} ; 15: M_{69.5} ; 16: M_{69.6} ; 17: M_{69.7}$; 18: $M_{69.8} ; 19: M_{69.9} ; 20: M_{11} ; 21: M_{14} ; 22: M_{18} ; 23: M_{25} ; 24: M_{44} ; 25: M_{60.4} ; 26: M_{66.3}$, uncut by Hae III.

\section{DISCUSSION}

Somatic incompatibility interactions among isolates of $C$. fusipes collected from two oak stands indicate that the population structure of this fungus is quite heterogeneous and composed of many genets within an infected stand.

The variability among isolates was very high for the two markers we studied, SIGs and IGS. As many as 43 different SIGs were detected in both stands on 31 and 34 trees, respectively. Among the 34 studied isolates from each stand, 9 and 14 different IGS $\left(I_{G S}+I G S_{2}\right)$ were detected, respectively. The IGS 2 was the most diverse. Even without restriction by Hae III, at least six different $\mathrm{IGS}_{2}$ types can be separated in Mersuay (Fig. 4) while just three IGS $_{1}$ types were present in the two stands (Table 2). The differences between the various $I_{G S}$ were mainly differences in the size and number of the amplified DNA fragments (Fig 4), which has already been observed (Bruns, White \& Taylor, 1991). The occurrence of these multiple bands may arise from heterogeneous IGS in the studied $C$. fusipes heterokaryons 
(i.e., several loci, divergent sequences in the two nuclei or within the same rDNA repeat). The presence of two bands for the $I \mathrm{GS}_{2}$ in several isolates was likely to have arise from difference in the sequence between the two nuclei because monokaryons obtained from some of those isolates had just one of the two bands (results not shown). Slower moving fragments of PCR products may also correspond to concatemeres or heteroduplexes formed by cross-hybridization between slighly different amplification products (Jensen \& Straus, 1993; Selosse et al., 1996). Sequencing of the fragment obtained using the primer pair revNS1 and rev5SA permitted us to check that we indeed amplified the $\mathrm{IGS}_{2}$ (result not shown).

A compatible interaction between two heterokaryons of the same species has often been taken as an indication that they belong to a same genet (Childs, 1963; Barrett \& Uscuplic, 1971; Kile, 1983; Kile, 1986; Guillaumin \& Berthelay, 1990; Holmer, Nitare \& Stenlid, 1994). It just indicates that the two isolates have common alleles at a small number of loci controlling the somatic incompatibility (Leslie, 1993). However, that SIGs are indeed genets has been recently verified by DNA analysis for Armillaria sp. (Smith et al., 1992; Smith, Bruhn \& Anderson, 1994) and for $P$. weirii (Bae, Hansen \& Strauss, 1994). This work showed that $C$. fusipes isolates belonging to the same SIG from the same tree always had identical IGS. In comparison, two isolates that belonged to different SIGs had both the same IGS 1 and the same $I_{2} S_{2}$ in just 52 out of the 2153 cases, i.e. $2.4 \%$ (Computed from Table 2). Moreover, isolates belonging to the same SIG and from the same tree were clustered on the root systems. Thus, the SIGs present on one tree could well be genets. Conversely, SIGs on a root system could represent groups of closely related isolates. However, synthetic heterokaryons of $C$. fusipes obtained by pairing sibling haploid strains together were shown to be compatible in only $10 \%$ of the cases (Marçais et al., in preparation). Moreover, the lightly pigmented interaction, rated as 1 in this work, represented about $65 \%$ of incompatible interactions between those sib-composed heterokaryons. These weaker interactions accounted for only $14 \%$ of the incompatible interactions between isolates from the same tree in Mersuay and for only $18 \%$ in Les Barres, a rate very close to the $12 \%$ found in both plots for incompatible interactions between isolates from different trees. Thus, our results do not support the second hypothesis and the SIGs are more probably genets. In contrast, in the few cases where $C$. fusipes isolates of the same SIG were present on different trees, they always had a different IGS 1 or a different IGS 2 and are thus likely to be different genets having common alleles at the loci controlling somatic incompatibility.

Isolates from neighbor infected trees were always found to belong to different genets. Thus, we found no evidence that $C$. fusipes is able to spread from tree to tree through root contacts. Infection and colonisation by this fungus occur mainly on the collar root of the tree (Marçais \& Delatour, unpublished results). This might partly explain why it spreads poorly by root contact to neighbor trees. The high number of genets occupying small areas within the two plots indicates that $C$. fusipes spreads in infected stands mainly by basidiospores. This is in agreement with the scattered distribution of $C$. fusipes in oak forest (Marçais \& Delatour, unpublished results). The tree might become infected by basidiospores germinating at the surface of the bark or alternatively, by mycelium growing free in the soil, as described for Phaeolus shweinitzii (Barrett \& Greig, 1984). 
We want to thank S. Crocco and J. E. Ménard for their technical assistance and P. Wargo for reviewing the manuscript. We also want to thank D. Piou and the C.E.M.A.G.R.E.F. for their help at the Les Barres stands and the D.S.F. for their help at the Mersuay stand.

\section{REFERENCES}

Bae, H., Hansen, E. M. \& Strauss, S. H. (1994). Restriction fragment length polymorphisms demontrate single origin of infection centers in Phellinus weirii. Canadian Journal of Botany 72, 440-447.

Barrett, D. K. \& Greig, B. J. W. (1984). Investigation into the infection biology of Phaeolus shweinitzii. In Proceedings of the Sixth International Conference on Root and Butt Rots of Forest Trees (ed. G. A. Kile), pp 95-103, CSIRO: Melbourne, Australia.

Barrett, D. K. \& Uscuplic, M. (1971). The field distribution of interacting strains of Polyporus schweinitzii and their origin. New Phytologist 70, 581-598.

Bruns, T. D., White, T. J. \& Taylor, J. W. (1991). Fungal molecular systematics. Annual Review of Ecology and Systematics 22, 525-564.

Buller, A. H. R. (1958). The perennial pseudorhiza of Collybia fusipes. In Researches on fungi, Vol. VI. pp 374-396, Hafner: New York, U.S.A.

Childs, T. W. (1963). Poria weirii root rot. Phytopathology 53, 1124-1127.

Delatour, C. \& Guillaumin, J. J. (1984). Un pourridié méconnu : le Collybia fusipes (Bull. ex Fr.) Quel. Compte-rendu de l'Académie d'Agriculture de France, 70, no1, 123-126.

Département de la santé des forêts (France) (1993). Ministère de l'Agriculture et de la pêche (DERF-DSF), 120 pp.

Guillaumin, J. J. \& Berthelay, S. (1990). Comparaison de deux méthodes d'identification des clones chez le Basidiomycète parasite Armillaria obscura (syn: A. ostoyae). European Journal of Forest Pathology 20, 257-268.

Guillaumin, J. J., Bernard, C., Delatour, C. \& Belgrand, M. (1985). Contribution à l'étude du dépérissement du chêne : pathologie racinaire en forêt de Tronçais. Annales des Sciences Forestières 42, 1-22.

Henrion, B., Le Tacon, F. \& Martin, F. (1992). Rapid identification of genetic variation of ectomycorrhizal fungi by amplification of ribosomal RNA genes. New Phytologist 122, 289-298.

Henrion, B., Chevalier, G. \& Martin, F. (1994). Typing truffles species by PCR amplification of the ribosomal DNA spacers. Mycological Research 98, 37-83.

Holmer, L., Nitare, L. \& Stenlid, J. (1994). Population structure and decay pattern of Phellinus tremulae in Populus tremula as determined by somatic incompatibility. Canadian Journal of Botany 72, 1391-1396.

Jensen, M. A., \& Strauss, N. (1993). Effect of PCR conditions on the formation of heteroduplex and single-stranded DNA products in the amplification of bacterial ribosomal DNA spacer regions. PCR Methods and Applications 3, 186-198.

Kile, G. A. (1983). Identification of genotypes and clonal development of Armillaria luteobubalina Watling and Kile in Eucalypt forest. Australian Journal of Botany 31, 657671. 
Kile, G. A. (1986). Genotypes of Armillaria hinnulea in wet sclerophyll Eucalypt forest in Tasmania. Transaction of the British Mycological Society 87, 312-314.

Leslie, J. F. (1993). Fungal vegetative compatibility. Annual Review of Phytopathology 31, 127-150.

Lewis, K. J., \& Hansen, E. M. (1991). Vegetative compatibility groups and protein electrophoresis indicate a role for basidiospores in spread of Inonotus tomentosus in spruce forests of British Columbia. Canadian Journal of Botany 69, 1756-1763.

Marçais, B. \& Delatour, C. (1996). Inoculation of Oak (Quercus robur and Q. rubra) with Collybia fusipes. Plant disease 80, 1391-1394.

Selosse, M., Costa, G., Di Battista, C., Le Tacon, F. \& Martin, F. (1996). Meiotic segregation and recombination of the intergenic spacer of the ribosomal DNA in the ectomycorrhizal basidiomycete Laccaria bicolor. Current Genetic 30, 332-337.

Smith, M. L., Bruhn, J. N. \& Anderson, J. B. (1992). The fungus Armillaria bulbosa is among the largest and the oldest living organisms. Nature 356, 428-431.

Smith, M. L., Bruhn, J. N. \& Anderson, J. B. (1994). Relatedness and spatial distribution of Armillaria genets infecting red pine seedlings. Phytopathology 84, 822-829.

White, T. J., Bruns, T., Lee, S. \& Taylor, J. (1990). Amplification and direct sequencing of fungal ribosomal RNA genes for phylogenetics. In PCR protocols. A guide to Methods and Applications (eds M. A., Innis, D. H., Gelfand, J. J., Sninsky \& T. J., White) pp 315322, Academic Press: San Diego, U.S.A.

Worrall, J. J. (1994). Population structure of Armillaria species in several forest types. Mycologia 86, 401-407. 